\title{
LOCAL WISDOM OF SEDULUR SIKEP (SAMIN) SOCIETY'S MARRIAGE IN KUDUS: PERSPECTIVE OF LAW NUMBER 1 YEAR 1974 ON MARRIAGE ${ }^{\Omega}$
}

\author{
Dwiyana Achmad Hartanto \\ Faculty of Law Universitas Muria Kudus, Indonesia \\ E-mail: dwiyana.achmad@umk.ac.id
}

\begin{abstract}
The research entitled "Local Wisdom of Sedulur Sikep (Samin) Society's Marriage in Kudus: Perspective ofLaw Number 1 of 1974 on Marriage" tried to reveal marriage practice of Sedulur Sikep (Samin) society in Kaliyoso, Karangrowo Village, Undaan Sub district, Kudus Regency. This research aims to (1) Find out the causal factors of why Sedulur Sikep (Samin) society in Kaliyoso, Karangrowo Village, Undaan Sub district, Kudus Regency unregister their marriage, (2) Discover the importance of marriage registration and find out the consequence of unregistered marriage. This research applied sociological juridical approach or empirical law research. The result of this research shows that Sedulur Sikep (Samin) society in Kaliyoso, Karangrowo Village, Undaan Subdistrict, Kudus Regency does not register their marriage since their custom or local wisdom does not recognize it which means that marriage registration is not an obligation. Marriage registration is crucial since it provides legal assurance toward any legal consequences appears due to marriage.
\end{abstract}

Keywords: local wisdom, marriage, sedulur sikep

\begin{abstract}
Abstrak
Penelitian dengan judul "Kearifan Lokal Perkawinan Masyarakat Sedulur Sikep (Samin) Di Kudus Pers pektif Undang-Undang Nomor 1 Tahun 1974 Tentang Perkawinan" dilakukan terhadap praktek perkawinan Masyarakat Sedulur Sikep (Samin) di Dukuh Kaliyoso Desa Karangrowo Kecamatan Undaan Kabupaten Kudus. Penelitian ini bertujuan (1) Menemukan faktor-faktor penyebab masyarakat Sedulur Sikep (Samin) di Dukuh Kaliyoso Desa Karangrowo Kecamatan Undaan Kabupaten Kudus tidak melakukan pencatatan perkawinan, (2) Mengetahui pentingnya pencatatan perkawinan dan akibat hukumnya terhadap perkawinan yang tidak dicatatkan. Metode pendekatan yang digunakan adalah metode pendekatan yuridis sosiologis atau penelitian hukum empiris. Hasil penelitian menunjukkan bahwa masyarakat Sedulur Sikep (Samin) di Dukuh Kaliyoso Desa Karangrowo Kecamatan Undaan Kabupaten Kudus tidak melakukan pencatatan perkawinan dikarenakan adat atau kearifan lokal mereka tidak mengenal adanya pencatatan perkawinan, tanpa pencatatan perkawinan pun tidak menimbulkan permasalahan. Terkait pencatatan perkawinan sangat penting karena dapat memberikan kepastian hukum terhadap akibat hukum yang timbul karena perkawinan.
\end{abstract}

Kata Kunci: kearifan lokal, perkawinan, sedulur sikep

Introduction

Marriage is a basic human right to preserve their descendants. Marriage in Indonesia is implemented differently due to cultural diversities. The enactment of Law Number 1 Year 1974 on Marriage (Marriage Law) signifies that there has been a unification of marriage law in Indonesia. The provisions of Article 2 paragraph (1) and (2) require a marriage is legal if it is in

$\Omega$ This paper is part of research Number: 002/LPM.UMK/C. 17.02/III/2016, on 7 March 2016. accordance with the religion and belief, besides it is registered under the provisions of the applicable law.

There are many cases of unregistered marriage in Indonesia, one of which is Sedulur Sikep (Samin) Society, Dukuh Kaliyoso, Karangrowo Village, Undaan Subdistrict of Kudus Regency. This practice often sparks controversy and deemed unlawful, because it does not involve government, both Religious Affairs Office (KUA) and Department of Population and Re- 
gistry. According to Zamhuri, ${ }^{1}$ the society's perception is not entirely correct. Even though they did not register their marriage, they believe that religious-based marriage is valid.

Indonesia is a religious country yet the 1945 Constitution also stated that Indonesia is a Law state (rechtstaat), which is any action taken must be based on law. ${ }^{2}$ The journey of national law in Indonesia is renewed, including marriage law with unification marriage law. The idea of national law renewal is inseparable from political, philosophical, sociological and other practical considerations derived from Customary Law, Islamic Law, and Western Law. It is interesting to study more as an effort to reform the national law, regarding unregistered marriage is valid, because it is in accordance with customary law and religion law.

\section{Problems}

Problems are formulated as follows: (1) What are the causal factors of Sedulur Sikep (Samin) Society in Dukuh Kaliyoso, Karangrowo Village, Undaan Subdistrict of Kudus Regency unregister the marriage? (2) What is the importance of marriage registration and the legal consequences of unregistered marriage?

\section{Research Method}

The method used is a sociological juridical approach method or empirical law research. The population of the research is the village apparatus and Sedulur Sikep (Samin) Society in Dukuh Kaliyoso, Karangrowo Village, Undaan Subdistrict of Kudus Regency, with the sample is 1 (one) village apparatus and 2 (two) residents of Sedulur Sikep (Samin) Society. The data used is primary data and secondary data. Data analysis technique using qualitative approach, which produce analytical descriptive data.

\footnotetext{
Zamhuri, April 092011, "Perkawinan Kaum Samin Terancam", available on website http://www.jurnal.umk.ac. id/pojok-muria-corner/551-perkawinan-kaum-samin-ter ancam, accessed on September $7^{\text {th }} 2016$.

2 Dwiyana Achmad Hartanto, "Kontribusi Hukum Islam Dalam Pembaharuan Hukum Pidana Di Indonesia (Studi Pidana Cambuk Di Nanggroe Aceh Darussalam)", Al-Ahkam Jurnal Ilmu Syari'ah Dan Hukum, Vol. 1 No. 2, July-December 2016, Surakarta: Faculty of Syari'ah IAIN Surakarta, page 172.
}

\section{Discussion}

Causal Factors of Sedulur Sikep (Samin) Society in Dukuh Kaliyoso, Karangrowo Village, Undaan Subdistrict of Kudus Regency Unregister the Marriage

Prior to the enactment of the Marriage Law, marriage practices in Indonesia vary: first, (Muslim) Indonesian hold religious law as a reception of customary law (receptio in complexu); second, Other than muslim Indonesian hold another customary law; third, (Christian) Indonesian hold Huwelijks Ordonantie Christen Indonesia (HOCl) S. 1933 Number 74; fourth, Chinese Foreign Easterners and Indonesian Citizens of Chinese descent apply the Civil Code by few amendment; fifth, other Foreign Easterners and other Indonesian citizens of foreign descent apply their own customary law; sixth, Europeans and people on their same level hold civil codes.

The establishment of Marriage Law indicates there is a national marriage law unification. Valid conditions and marriage registration stated in article 2 of Marriage Law:

(1) Marriage is valid, if it held according to their religious law;

(2) Every marriage is registered according to the prevailing laws and regulations.

According to $M$. Idris Ramulyo there are 2 opinions on the interpretation of Article 2 of Marriage Law: ${ }^{3}$ First, Separate the interpretation of article 2 paragraph (1) from paragraph (2), in terms that registration is only administrative requirements which does not cause a valid marriage to be invalid for those who do not perform it; Second, bringing together the article 2 paragraph (1) with paragraph (2), the validity of marriage cannot be seen through juridical view only. Rather, it must be associated with a sociological view. A marriage is valid if it is held according to their own religious law and marriage registration is unity.

Marriage of Sedulur Sikep (Samin) Society in Dukuh Kaliyoso, Karangrowo Village, Undaan

3 Moh. Idris Ramulyo, 1990, Tinjauan Beberapa Pasal Undang-undang Nomor 1 tahun 1974 Dari Segi Hukum Perkawinan Islam, Jakarta: IDN-HILL-CO, page 92. 
Subdistrict of Kudus Regency is implemented by preserving and practicing the teachings of Adam and values of local wisdom, namely Serat Pikukuh Kasejaten (gospel ordinances and laws on marriage of Sedulur Sikep), with marriage steps: ${ }^{4}$ First, Nyumuk period. Namely the male parents propose the female parent for their daughter, whether her daughter is still single. Second, Ngendek period. The statement of the male parents to female parents, preceded by groom's statement to her parents (at bride's home), that he intends to marry their daughter. The groom's mother gives dowries to the bride. This period is attended by leading figures and families of Sedulur Sikep (Samin), and neighbors who adhere to the teachings of Samin and non Samin. Third, Nyuwitha and ngawulo period. The day of marriage based on the groom's intention to continue descent (wiji sejati, titine anak Adam). After nyuwito, the groom lives together with bride's family in one house or otherwise by agreement between the parents in law. During ngawulo, the newlywed help their parents' job. There is no time limit in ngawulo, just waiting for the newlywed match, indicated by sexual intercourse. Fourth, Paseksen or $\mathrm{Ne}$ sekna, is a statement from the host of ngawulo, that I have a daughter (daughter's name) has been proposed by a man (the name of the man), that the Sikep's steps have been executed (Sikep: laki rabi). The statement is uttered in front of the forum, and answered: "yes". Then it is followed by the groom's statement, which the bridegroom has promised, it will be once for forever to marry the woman, then forum answer is: "Yes".

The marriage principle of Sedulur Sikep adheres to the principle of monogamy (married for once in a lifetime). Thus they do not recognize divorce. The marriage registration is not performed because their understanding of marriage is based on Adam's religious teachings and their customs do not recognize marriage regist-

Wargono, the elders of Sedulur Sikep (Samin) society in Dukuh Kaliyoso, Karangrowo Village, Personal Interview, on March $2^{\text {nd }} 2016$. ration. ${ }^{5}$ According to Adam's religion professed by Sikep Sedulur (Samin) Society, registrations of marriages were unknown in customs. Sikep means laki rabi were commonplace in everyday life and does not recognize divorce, polygamy and polyandry, so the marriage registration is not required. ${ }^{6}$

The marriage practice of Sedulur Sikep (Samin) society in Sambongrejo Village, Sambong Subdistrict, Blora Regency is customarily conducted, not to be registered in Religious Affairs Office, since Samin they are waiting for legal protection to place customary marriage legally. ${ }^{7}$ According to them, unregistered marrige is considered valid if it complies with the rules/ customary laws of Sedulur Sikep (Samin) society, which follows the rules of Serat Jamus Kalimosodo (Serat Pikukuh Kasejaten). ${ }^{8}$ Under Law Number 23 Year 2006 on Population Administration, demographic events such as births, changes of address, marriages, divorces, legalization children, to death must be reported to government agencies for its poplulation implications. According to the community of Sedulur Sikep (Samin) in Kudus, the registration is deemed invalid because it is not taught by their ancestors. ${ }^{9}$

The existence of unregistered marriage practices signifies ineffective law implementation. According to Robert B. Seidman, the theory of legal work is described as follows:

5 Noor Hadi, Karangrowo Village Officer, Personal Interview, onFebruary $25^{\text {th }} 2016$.

6 Niti Rahayu, Member of Sedulur Sikep (Samin) Society in Dukuh Kaliyoso Karangrowo Village, Personal Interview, on March $2^{\text {nd }} 2016$.

7 Suhanah, "Dinamika Perkembangan Sistem Kepercayaan Samin di Kabupaten Blora", HARMONI Jurnal Multikultural \& Multireligius, Vol. X No. 3, July-September 2011, Jakarta: Center for Research and Development of Religious Life Agency for Research on Development and Education Training Ministry of Religious Affairs of Republic Indonesia, page 620.

8 Moh. Agus Prasetiyo, et.al., "Pelaksanaan Perkawinan Dan Pewarisan Masyarakat Adat Sedulur Sikep Desa Baturejo, Kecamatan Sukolilo, Kabupaten Pati”, Jurnal Sosial Budaya, Vol. 7 No. 1, June 2014, Kudus: Universitas Muria Kudus, page 26.

9 Moh. Rosyid, "Perkawinan Masyarakat Samin Dalam Pandangan Hukum Negara", "Analisa” Journal of Social Science and Religion, Vol. XVII No. 01, January-June 2010, Semarang: Ministry of Religious Affairs of Republic of Indonesia, page 19 


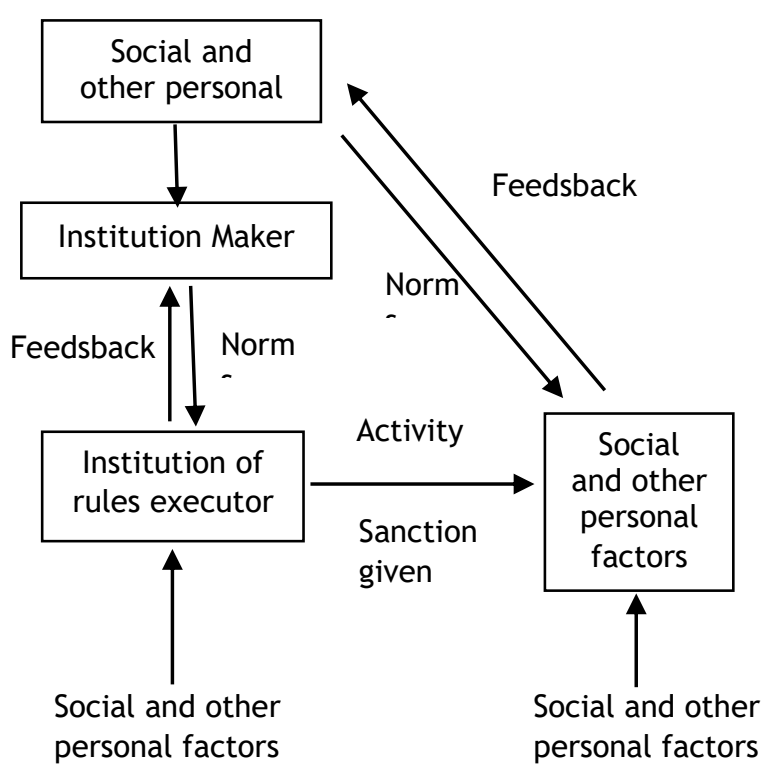

Robert B. Seidman sees that each law telling how a role-holder is expected to act in response to the function of the rules addressed to him, the sanctions, activities of the implementing agency, and the overall social, politic, economic, and cultural aspects. Law is seen as a whole system that are: First, One purpose-oriented; Second, More than numbers and parts; Third, Interact with other larger systems; Fourth, The working of the parts creates something of value. ${ }^{10}$

The chart above can be explained as follows: First, The institution maker is the House of Representatives of Indonesia (DPR RI) as the power holder to form a law and passed by the president. The social and personal power of the community, private as well as NGOs influences the legislature; Second, The Government (Kudus Regency) as the Regulatory Authority, acts in response to the established Law. At this stage, social and personal forces play a role in the continuity of the Law; Third, Society (Sedulur Sikep) as the role holder, is the object of the enactment of the Law which is responded through the action, in the form of compliance or non-compliance as a feedback.

This research reveals the law cannot work effectively because the role holder (community)

10 Robert B. Seidman, 1978, The State Law and Development, Massachussets: Addision Wesley Publishing Company, page 75 . has not performed its function and the Regulatory Agency cannot enforce norms and sanctions either due to customary provisions as the basis of marriage of the community.

Related to the effectiveness of the rule of law, there are 2 (two) legal functions, namely as a means of social control and a means of social engineering. According to Michael Hager, the legal function as a tool of social engineering serves 3 (three) sectors: Ordering, balancing, and a catalyst, helping to facilitate change through law reform (Law Reform). The concept of law as a tool of social engineering stated by Roscoe Pounds means that law is not only used to keep themselves in power but also serves as a tool of social engineering. According to Mochtar Kusuma Atmaja, law as a tool of social engineering means that law not only serves as a tool but also a means of renewal or community development. ${ }^{11}$

Efforts in the promotion of national law, no need to be contradicted if legal reform is done through legislation as a tool/tool of engineering is made on the basis of values or aspirations that live and thrive in society or on the basis of the life experience of community law. This is in accordance with the laws of political founding fathers, who put the customary law as a source of formation of national law.

The Importance of Registered Marriage and Their Legal Effects on Unregistered Marriage

The provisions of article 2, paragraph (2) of Marriage Law states: "Every marriage is registered in accordance with the prevailing legislation". This article requires marriage besides in accordance with the law and their respective beliefs, it shall be registered which is in line with Regulation Number 9 Year 1975 and the Regulation of the Minister of Religion Number 3 and 4 Year 1975. Juridically, the state does not recognize an unregistered marriage (Sirri, custom marriage, etc.). According to Lastuti Abu-

\footnotetext{
Mochtar Kusuma Atmaja, 1986, Pembinaan Hukum Dalam Rangka Pembaharuan Hukum Nasional, Bandung: Binacipta, page 13 .
} 
bakar, ${ }^{12}$ by the enactment of the Marriage Law, customary law marriages are not considered as binding law and does not bring legal consequences either. As a result, the existence of customary law is irrelevant.

The recommendation of marriage registration has been urged long before the Marriage Law was issued, at the National Law Seminar I in Jakarta on 11 March 1963 in the Principles of National Legal Procedures about Marriage Law which suggested registered marriages ${ }^{13}$ According to Trusto Subekti, marriage registration is an institutional behavior and decisions that reflect the will of state establishment and the product of a decision or other form of Marriage Law establishment. ${ }^{14}$

According to Bagir Manan, Article 2 Paragraph (2) of Marriage Law explains that marriage registration is the same as recording important events, such as births, deaths, etc., so it is necessary to provide legal certainty for the parties. ${ }^{15}$ The provisions of Article 2 paragraph (2) of the Marriage Law indicate a legal marriage and have binding force not only for husband and wife, but also third parties (other people) and there are no losers in the presence of the marriage, and has a strategic value in the form of recognition and protection of the state. ${ }^{16}$

Marriage registration is crucial as administrative requirement, to prove that marriage truly happens, which is beneficial for couple, family, other people, or the society since it is

12 Lastuti Abubakar, "Revitalisasi Hukum Adat Sebagai Sumber Hukum dalam Membangun Sistem Hukum Indonesia", Jurnal Dinamika Hukum, Vol. 13 No. 2, May 2013, Purwokerto: Faculty of Law, Universitas Jenderal Soedirman, page 327.

13 Barda Nawawi Arief, 2009, Kumpulan Hasil Seminar Hukum Nasional Ke I s/d VIII dan Konvensi Hukum Nasional 2008, Semarang: Pustaka Magister Semarang, page 4.

14 Trusto Subekti, "Studi Perkembangan Substansi Kutipan Akta Perkawinan Bagi non Muslim Setelah Berlakunya Undang-Undang Nomor 1 Tahun 1974 Pada Dinas Kependudukan Dan Catatan Sipil Kabupaten Banyumas", Jurnal Dinamika Hukum, Vol. 10 No. 1, January 2010, Purwokerto: Faculty of Law Unviersitas Jenderal Soedirman, page 15.

15 Moh. Agus Prasetiyo, et.al., Loc It.

16 Trusto Subekti, "Sahnya Perkawinan Menurut UndangUndang Nomor 1 Tahun 1974 Tentang Perkawinan Ditinjau Dari Hukum Perjanjian”, Jurnal Dinamika Hukum, Vol. 10 No. 3, September 2010, Purwokerto: Faculty of Law, Universitas Jenderal Soedirman, page 338. enclosed in an official letter that can be used as an authentic written proof. ${ }^{17}$ Marriage without Marriage Registration Officer Management is considered breaking law. However, this violation is administrative which means that the marriage registration is not the legal requirement for marriage. The aim of registration is stated in the explanation of article 1 paragraph (1), which is to obtain the law certainty and order. ${ }^{18}$ Marriage creates new position, from no status in marriage to have the bounding status in marriage as the husband and wife. It requires the state to give law recognition of the marriage by doing legal marriage registration. ${ }^{19}$ Even though as an administrative requirement, marriage registration has important function as one of the authentic written proofs. ${ }^{20}$

There is a legal breakthrough related to the material test proposed at Constitutional Court towards the provision of article 43 paragraph (1) on Marriage Law, through Constitutional Court's Verdict Number 46/PUU-VIII/ 2010. Moh. Mahfud argued that the verdict is crucial and revolutionary, because all of the children born from unmarried parents, either sirri or love affair, have a civil relationship with their father. In addition, this provision also applies to men who have relationship without marriage. The consequence is, the men have to be responsible for the child born. ${ }^{21}$ However, a registered marriage aims to obtain law legality. Unregistered marriages considered illegal, so

17 Dian Mustika, “Pencatatan Perkawinan Dalam UndangUndang Hukum Keluarga Di Dunia Islam”, INOVATIF Jurnal Ilmu Hukum, Vol. 4 No. 5, 2011, Jambi: Unviersitas Jambi, page 55 .

18 Supani, "Pencatatan Perkawinan Dalam Teks PerundangUndangan Perkawinan Di Beberapa Negara Islam Perspektif Usul Fikih", Jurnal Al-Manahij, Vol. 5 No. 1, 2011, Purwokerto: Sekolah Tinggi Agama Islam Negeri Purwokerto, page 4.

19 Abdullah Tri Wahyudi, "Universalitas dan Partikularitas Hak Asasi Manusia dalam Undang-Undang Nomor 1 Tahun 1974 Tentang Perkawinan", Al-Ahkam Jurnal Ilmu Syari'ah Dan Hukum, Vol. 1 No. 1, January-June 2016, Surakarta: Faculty of Syari'ah IAIN Surakarta, page 98.

20 Masruhan, "Pembaruan Hukum Pencatatan Perkawinan Di Indonesia Perspektif Maqasid Al-Shari'ah", At-Tahrir Jurnal Pemikiran Islam, Vol. 13 No. 2, November 2013, Ponorogo: STAIN Ponorogo, page 237.

21 Rachmadi Usman, "Prinsip Tanggung Jawab Orangtua Biologis terhadap Anak Di Luar Perkawinan”, Jurnal Konstitusi, Vol. 11 No. 1, March 2014, Jakarta: Mahkamah Kontitusi of The Republic of Indonesia, page 171. 
that the wife and the children do not have law protection such as civil relationship with the father. ${ }^{22}$ On the other hand, Constitutional Court's Verdict gives the solution for the unregistered marriage because the recognition of children's rights can be done through DNA testing or other ways according to technology advance.

The absence of unregistered marriage regulation causes the absence of law protecttion. Consequently, it requires more study on how to draft regulation that can give certainty and law protection by more specific rules. Moreover, National law development needs further study through culture and local wisdom perspective by exploring law living in society (customary law and Islamic law) besides western law. This is based on Article 1 of People's Consultative Assembly's Verdict Number 3 Year 2000.

Customary provisions that exclude marriage registration is a local wisdom afterall. Without registration, the Sedulur Sikep (Samin) Society has never experienced a domestic conflict. This is adoptable yet regulation by specific formulation to accommodate customary law within national law renewal.

\section{Conclusion}

Sedulur Sikep (Samin) Society in Dukuh Kaliyoso, Karangrowo Village, Undaan Subdistrict of Kudus Regency do not register their marriage to preserve and to implement Adam's religion and the values of local wisdom. Society as the role holder respond it by disobedience as a feedback of Marriage Law implementation. As a result law as a tool of social engineering is not effectively implemented.

The importance of marriage registration and the legal effects towards the unregistered marriage is that unregistered marriage cannot provide the protection and legal assurance. Thus, the provisions of law marriage have to be

22 Achmad Irwan Hamzani, "Nasab Anak Luar Kawin Pasca Putusan Mahkamah Konstitusi Nomor 46/PUU-VIII/2010", Jurnal Konstitusi, Vol. 12 No. 1, March 2015, Jakarta: Mahkamah Konstitusi of The Republic of Indonesia, page 58. considered as the law source in renewing national law.

\section{Suggestion}

Society of Sedulur Sikep (Samin) willingly approve and perform the regulation of Marriage Law, so it will create legal assurance and law protection as well as the law as a tool of social engineering functions well. The role of Kudus Regency Government, academician, NGO, and other institutions through socialization and guidance in marriage registration implementation are encouraged.

\section{References}

Arief, Barda Nawawi. 2009. Kumpulan Hasil Seminar Hukum Nasional Ke I s/d VIII dan Konvensi Hukum Nasional 2008. Semarang: Pustaka Magister Semarang;

Ramulyo, Moh. Idris. 1990. Tinjauan Beberapa Pasal Undang-undang Nomor 1 tahun 1974 Dari Segi Hukum Perkawinan Islam. Jakarta: IDN - HILL - CO;

Kusuma Atmaja, Mochtar. 1986. Pembinaan Hukum Dalam Rangka Pembaharuan Hukum Nasional. Bandung: Binacipta;

Seidman, Robert B. 1978. The State Law and Development. Massachussets: Addision Wesley Publishing Company;

Abubakar, Lastuti. "Revitalisasi Hukum Adat Sebagai Sumber Hukum dalam Membangun Sistem Hukum Indonesia". Jurnal Dinamika Hukum, Vol. 13 No. 2. May 2013. Purwokerto: Faculty of Law Unviersitas Jenderal Soedirman;

Hamzani, Achmad Irwan. "Nasab Anak Luar Kawin Pasca Putusan Mahkamah Konstitusi Nomor 46/PUU-VIII/2010". Jurnal Konstitusi, Vol. 12 No. 1. March 2015. Jakarta: Mahkamah Konstitusi of The Republic of Indonesia;

Hartanto, Dwiyana Achmad. "Kontribusi Hukum Islam Dalam Pembaharuan Hukum Pidana Di Indonesia (Studi Pidana Cambuk Di Nanggroe Aceh Darussalam)". Al-Ahkam Jurnal Ilmu Syari'ah Dan Hukum, Vol. 1 No. 2. July-December 2016. Surakarta: Faculty of Syari'ah IAIN Surakarta;

Masruhan. "Pembaruan Hukum Pencatatan Perkawinan Di Indonesia Perspektif Maqasid Al-Shari'ah". At-Tahrir Jurnal Pemikiran 
Islam, Vol. 13 No. 2. November 2013. Ponorogo: STAIN Ponorogo;

Mustika, Dian. "Pencatatan Perkawinan Dalam Undang-Undang Hukum Keluarga Di Dunia Islam". INOVATIF Jurnal Ilmu Hukum, Vol. 4 No. 5. 2011. Jambi: Universitas Jambi;

Prasetiyo, Moh. Agus, dkk. "Pelaksanaan Perkawinan Dan Pewarisan Masyarakat Adat Sedulur Sikep Desa Baturejo, Kecamatan Sukolilo, Kabupaten Pati”. Jurnal Sosial Budaya. Vol. 7 No. 1. June 2014. Kudus: Unviersitas Muria Kudus;

Rosyid, Moh. "Perkawinan Masyarakat Samin Dalam Pandangan Hukum Negara". Analisa Journal of Social Science and Religion, Vol. XVII No. 01. January - June 2010. Semarang: Ministry of Religious Affairs of The Republic of Indonesia;

Subekti, Trusto. "Studi Perkembangan Substansi Kutipan Akta Perkawinan Bagi non Muslim Setelah Berlakunya Undang-Undang Nomor 1 Tahun 1974 Pada Dinas Kependudukan Dan Catatan Sipil Kabupaten Banyumas". Jurnal Dinamika Hukum. Vol. 10 No. 1. January 2010. Purwokerto: Faculty of Law Universitas Jenderal Soedirman;

Subekti, Trusto. "Sahnya Perkawinan Menurut Undang-Undang Nomor 1 Tahun 1974 Tentang Perkawinan Ditinjau Dari Hukum Perjanjian". Jurnal Dinamika Hukum. Vol. 10 No. 3. September 2010. Purwokerto: Faculty of Law, Universitas Jenderal Soedirman;

Suhanah. "Dinamika Perkembangan Sistem Kepercayaan Samin di Kabupaten Blora". HARMONI Jurnal Multikultural \& Multireligius, Vol. X No. 3. July-September 2011. Jakarta: Center for Research and Development of Religious Life Agency for Research on Development and Education Training Ministry of Religious Affairs of Republic Indonesia;

Supani. "Pencatatan Perkawinan Dalam Teks Perundang-Undangan Perkawinan Di Beberapa Negara Islam Perspektif Usul Fikih". Jurnal Al-Manahij. Vol. 5 No. 1. 2011. Purwokerto: Sekolah Tinggi Agama Islam Negeri Purwokerto;

Usman, Rachmadi. “Prinsip Tanggung Jawab 0rang tua Biologis terhadap Anak Di Luar Perkawinan”. Jurnal Konstitusi. Vol. 11 No. 1. March 2014. Jakarta: Mahkamah Konstitusi of The Republic of Indonesia;
Wahyudi, Abdullah Tri. "Universalitas dan Partikularitas Hak Asasi Manusia dalam Undang-Undang Nomor 1 Tahun 1974 Tentang Perkawinan". Al-Ahkam Jurnal Ilmu Syari'ah Dan Hukum. Vol. 1 No. 1. January-June 2016. Surakarta: Faculty of Syari'ah IAIN Surakarta;

Zamhuri, April 09th 2011. "Perkawinan Kaum Samin Terancam", available on website http://www.jurnal.umk.ac.id/pojok-mu ria-corner/551-perkawinan-kaum-saminterancam. Accessed on September $7^{\text {th }}$ 2016. 